\title{
Vegetative rescue and ex vitro system production of Tibouchina sellowiana clonal plants by cutting and mini-cutting
}

\author{
Rosimeri de Oliveira Fragoso ${ }^{{ }^{*}}$ Carlos André Stuepp ${ }^{1}$ Francielen Paola de Sá ${ }^{1}$ \\ Dagma Kratz ${ }^{2}$ Katia Christina Zuffellato-Ribas ${ }^{3}$ Ivar Wendling ${ }^{4}$
}

\footnotetext{
'Programa de Pós-graduação em Agronomia - Produção Vegetal, Universidade Federal do Paraná (UFPR), 80035-050, Curitiba, PR, Brasil. E-mail: meri_ol@yahoo.com.br. "Corresponding author.

${ }^{2}$ Departamento de Ciências Florestais, Universidade Federal do Paraná (UFPR), Curitiba, PR, Brasil.

${ }^{3}$ Departamento de Botânica, Universidade Federal do Paraná (UFPR), Curitiba, PR, Brasil.

${ }^{4}$ Embrapa Florestas, Colombo, PR, Brasil.
}

\begin{abstract}
We aimed to evaluate the rooting potential of Tibouchina sellowiana through the experiments: I - Cuttings from current-year shoots and epicormic shoots were submitted to IBA concentrations: 0, 500,1000, 1500 and 2000mg $L^{-1}$, in a factorial arrangement $2 \times 5$ (two types of cuttings $x$ five IBA concentrations), with four replicates and 20 cuttings each; II - mini-stumps of Tibouchina sellowiana were submitted to successive shoots collecting during the four seasons, in a split-plot design, with five replications of ten mini-stumps per experimental unit. From the shoots of mini-stumps, mini-cuttings were produced, which were initially kept in greenhouse and later transferred to full sun, in a 4 $x 5$ factorial arrangement (four seasons $x$ five collections per season), with four replicates of 12 mini-cuttings. Superiority of epicormic shoots cuttings was reported when compared to the current-year shoots, which showed the highest rooting and leaves maintenance $(42.50 \%$ and $55.00 \%$, respectively), eliminating the use of IBA. High survival of mini-stumps (over 80\%) and the mini-cuttings production (170mini-cuttings $m^{-2}$ month $^{-1}$ ) in clonal mini-garden and the mini-cuttings survival (above 80\%) in the greenhouse demonstrated the technical feasibility, with summer as the most appropriate time to collect mini-cuttings.
\end{abstract}

Key words: auxin, clonal mini-garden, ornamental species, rejuvenation, vegetative propagation.

Resgate vegetativo e sistema ex vitro de produção de mudas de Tibouchina sellowiana por estaquia e miniestaquia

RESUMO: Objetivou-se avaliar o potencial de enraizamento de Tibouchina sellowiana por meio dos experimentos: I - Estacas provenientes de brotações do ano e epicórmicas foram submetidas às concentrações de IBA: 0, 500, 1000, 1500 e $2000 \mathrm{mg} \mathrm{L}^{-1}$, em arranjo fatorial $2 x 5$ (dois tipos de estacas x cinco concentrações de IBA), com quatro repetições de 20 estacas cada; II - Minicepas de Tibouchina sellowiana foram submetidas à coletas sucessivas de suas brotações durante as quatro estações do ano, em modelo de parcelas subdivididas no tempo, com cinco repetições de dez minicepas por unidade experimental. A partir das brotações das minicepas foram produzidas miniestacas, as quais foram inicialmente mantidas em casa de vegetação e posteriormente transferidas para pleno sol, em arranjo fatorial $4 x 5$ (quatro estações do ano $x$ cinco coletas por estação), com quatro repetições de 12 miniestacas. Verificou-se superioridade das estacas de brotações epicórmicas em comparação às brotações do ano, as quais apresentaram o maior enraizamento e retenção foliar $(42,50 \%$ e 55,00\%, respectivamente), dispensando o uso de IBA. A elevada sobrevivência das minicepas (superior a 80\%) e produção de miniestacas (170 miniestacas m $^{-2}$ mês ${ }^{-1}$ ) em minijardim clonal e sobrevivência (acima de 80\%) de miniestacas em casa de vegetação demonstram a viabilidade da técnica, sendo o verão a época mais adequada para coleta de miniestacas.

Palavras-chave: auxina, minijardim clonal, espécie ornamental, rejuvenescimento, propagação vegetativa.

\section{INTRODUCTION}

Tibouchina selowiana (Cham.) Cogn - Melastomataceae, popularly known as manacáda-serra, is a pioneer and arboreal species. It has considerable commercial importance, which is mainly due to its ornamental potential, largely grown in landscaping for its flowering (NIENOW et al., 2010).

The sexual reproduction of species presents some disadvantages, such as low germination rates, slowness and uniformity of the plants (BARBOSA et al., 1988). Because of such difficulties, vegetative propagation can be a viable option due to the ease 
of cloning. Among the different methods, cutting and mini-cutting technique are characterized by inducing root formation in cuttings and mini-cuttings (DIAS et al., 2012). Among the main limitations of roots formation we found the ontogenetic age of propagules, determining factor in the formation of adventitious roots, where, in general, propagules with a higher degree of juvenility tend to have higher rooting and vigor (XAVIER et al., 2009; WENDLING et al., 2010). Lignification is directly related to the ontogenetic age of the plant material. Vegetative propagules with less ontogenetic age, such as currentyear shoots, are preferentially used because they lodge less degree of lignification and endogenous hormonal balance favorable to the emission of roots (HUSEN \& PAL, 2007; WENDLING et al., 2015).

In cutting technique, rejuvenated plants can be achieved with clear cutting or through a drastic pruning in mature trees for induction of epicormic shoots (STUEPP et al., 2014; RICKLI et al., 2015). However, the mini-cutting presents some advantages over cuttings, as size reduction of cuttings and increased shoots productivity per area, and youth use of propagules (DIAS et al., 2012).

Given the importance of developing an efficient system production of Tibouchina sellowiana clonal plants, we aimed to compare the rooting potential of cuttings coming from current-year shoots and epicormic shoots under different concentrations of indole butyric acid (IBA) (Experiment I), and to verify the efficiency of mini-cuttings technique and management of clonal mini-garden for the rooting and productivity of mini-cuttings (Experiment II).

\section{MATERIALS AND METHODS}

\section{Experiment I - current-year shoots and epicormic} shoots

The experiment was conducted between October 2012 and January 2013, in Curitiba (PR), Brazil $\left(25^{\circ} 44^{\prime} \mathrm{S}\right.$ and $\left.49^{\circ} 23^{\prime} \mathrm{W}, 920 \mathrm{~m}\right)$. Collection of plant material occurred from mother plants with about 6 to 10 years old, located in Aurora (SC), Brazil (27 $23^{\prime}$ 'S and $\left.49^{\circ} 38^{\prime} \mathrm{W}, 700 \mathrm{~m}\right)$. Two types of cuttings were made: cuttings from current-year shoots and cuttings from epicormic shoots pruned in July 2012.

Both cuttings were made from semi hard wood material, $12 \pm 1 \mathrm{~cm}$ long, with cut beveled at the bottom and right above the last apical bud, with two sheets reduced to $1 / 3$ of its surface. Disinfection has been carried out with sodium hypochlorite at $0.5 \%$ for 10 minutes, followed by washing in running water for 10 minutes. Subsequently, the base of the cuttings was treated with plant growth regulator indole-butyric acid (IBA) for 10 seconds of immersion, according to the following treatments (T): 0 (distilled water solution and $98 \%$ ethanol 1 : 1), 500, 1000, 1500 and $2000 \mathrm{mg} \mathrm{L}^{-1}$ (50\% hydroalcoholic solution 1:1) (STUEPP et al., 2014). Planting was carried out in plastic tubes of $55 \mathrm{~cm}^{3}$, filled with fine-grained vermiculite and carbonized rice hull (1:1), placed in acclimatized greenhouse with intermittent mist (average temperature of $24 \pm 2^{\circ} \mathrm{C}$ and $85 \%$ relative humidity).

After 60 days in the greenhouse, the following variables were evaluated: percentage of rooting; number of roots cutting ${ }^{-1}$; length of the three longest roots cutting $^{-1}$; survival percentage (alive cuttings without roots or calluses); percentage of cuttings with callus (alive cuttings without roots, with undifferentiated cells formation on the base); mortality percentage and original leaves maintenance. The experimental design was completely randomized in a factorial arrangement 2 $\mathrm{x} 5$ (two types of cuttings $\mathrm{x}$ five IBA concentrations), with four replicates and 20 cuttings each.

\section{Experiment II - clonal mini-garden management and mini-cutting}

The Tibouchina sellowiana clonal minigarden, formed from clonal plants produced by cuttings, was conducted in a shade house $(50 \%$ irradiance), in pots of $2 \mathrm{~L}$ containing commercial substrate coconut and peat fiber base, with a spacing $20 \times 20 \mathrm{~cm}$, periodic irrigation (micro sprinkler three times a day for 10 minutes) and weekly fertigation $(25 \mathrm{ml}$ of a nutrient solution composed of $4 \mathrm{~g} \mathrm{~L}^{-1}$ ammonium sulfate, triple superphosphate and potassium chloride and $1 \mathrm{~g} \mathrm{~L}^{-1}$ FTE BR-12) (STUEPP et al., 2016).

The first mini-stumps pruning occurred 90 days after the plants adjustment period, aiming to homogenize shoots. It was performed $10 \mathrm{~cm}$ above the collar region, maintaining at least two leaves. After that, shoots collections took place every 20 days, with five collections per season, totaling 20 collections. In order to make the mini-cuttings, only major shoots were collected, $10 \mathrm{~cm}$ in length and with more than three pairs of leaves.

Mini-cuttings were made with $8 \pm 1 \mathrm{~cm}$ and a mean diameter of $0.4 \pm 0.1 \mathrm{~cm}$, with cut beveled at the bottom and right above the last apical bud, maintaining two sheets reduced to $1 / 3$ of their surface. Planting was carried out in plastic tubes of $55 \mathrm{~cm}^{3}$, filled with fine-grained vermiculite and carbonized rice hull (1:1), all put in a greenhouse. After 60 days, 
they were transferred to a full sun condition, with micro sprinkler irrigation (three daily irrigations, 5 minutes long and flow of $144 \mathrm{~L}_{\text {hour }}{ }^{-1}$ ) where they remained until 90 days.

Assessments occurred between June 2013 and May 2014, during the four seasons. They were evaluated: survival percentage of mini-stumps (SM), production of mini-cuttings $\mathrm{m}^{-2} \mathrm{month}^{-1}$ (PMQ) and production of mini-cuttings mini-stump ${ }^{-1}(\mathrm{PMC})$. The experimental design was completely randomized, in a split-plot design, with five replicates of $10 \mathrm{mini}-$ stumps for each experimental unit.

We opted for the non-destructive method of evaluation, so the mini-cuttings were evaluated in two stages: in the greenhouse and in full sun. Evaluations in the greenhouse were: percentage of survival at 45 DAI (days after instalation); percentage of survival at 60 DAI (exit of the greenhouse); percentage of roots emission in the plastic tube bottom (RFT) at 60 DAI. Assessments in full sun were: percentage of mini-cuttings survival at $90 \mathrm{DAI}$; percentage of shoots emission in mini-cuttings at 90 DAI. The experimental design was completely randomized with factorial arrangement $4 \times 5$ (4 seasons $x 5$ collections per season), with four replicates of 12 mini-cuttings each.

All variances (Experiments I and II) were evaluated for homogeneity by Bartlett test, and the averages numbers compared by Tukey test at 5\% probability using the statistical program Assistat 7.7.

\section{RESULTS AND DISCUSSION}

Experiment I - current-year shoots and epicormic shoots

According to the data analysis there was a significant interaction between the cuttings and the application of IBA for all variables except for the percentage of cuttings with callus and root length (Table 1). In general, it was reported that the increase in IBA concentrations caused inverse effect on both types of cuttings. In cuttings from currentyear shoots, there was a gradual increase in the percentage of rooting, survival, leaves maintenance, and decrease of the mortality percentage, compared to the increase of the regulator. Therefore, for cuttings from epicormic shoots, as they raised concentrations of IBA, there was a decrease in the percentage of rooted cuttings, vivid and original leaves, and increased mortality (Table 1).

Reduction in rooting capacity may have been due to differences in the endogenous concentrations of plant hormones from the two types of plant material used. Among the factors that influenced the content of endogenous auxin are the age (OSTERC \& STAMPAR, 2011) and physiological conditions (WENDLING et al., 2014). Cuttings obtained from epicormic shoots, with more youthful and vigor material (RICKLI et al., 2015) in relation to the currentyear shoots, possibly possessed sufficient endogenous auxin that induced rooting. In this case, the addition of exogenous auxin generated a phytotoxic effect on the propagule, as has been observed for other species, and the concentration of IBA became harmful (NIENOW et al., 2010; FRAGOSO et al., 2015). Conversely, when the endogenous auxin level is insufficient, the application of synthetic auxins less sensitive to photooxidation, such as IBA, became important to promote an appropriate hormonal balance that encourages rooting of cuttings (XAVIER et al., 2009), as observed for the material from the current-year shoots.

There was a direct relationship between the roots and the leaves maintenance in both types of materials, showing the importance of these both for survival and for the formation of roots. Some compounds present in buds and leaves, such as auxin and cofactors can be translocated though phloem to the base of the cuttings, stimulating rooting (BONA \& BIASI, 2010). Furthermore, regarding the formation of callus, there was no significant interaction between the factors and, the low percentages obtained (Table 1) may be an indication that the formation of roots in Tibouchina sellowiana occurs directly, without requiring callus formation and subsequent differentiation and redifferentiation in these roots.

Regarding the number of roots, unlikely observed in rooting, as more as IBA concentrations were increasing, cuttings of epicormic shoots presented higher values than the current-year shoots (Table 1). The largest number of roots in this type of material is once again related to its most youthful vigor. Despite the growth regulator caused a reduction in the percentage of rooting in epicormic shoots cuttings, those that had taken root showed a higher development compared to the cuttings coming from the current-year shoots. The greater increment in roots results in better absorption of water and nutrients from soil, making the plant more capable to withstand harsh environment conditions (FREITAS et al., 2005). The positive effect of the application of IBA on the greater emission of adventitious roots was observed in other forest species, mainly in rejuvenated propagules (STUEPP et al., 2014; PEREIRA et al., $2015 \mathrm{a})$. IBA promotes the induction of a greater root system by influencing the hydrolysis of 
Table 1 - Averages of rooting, leaves maintenance, survival, mortality and callus formation percentages, number of roots cutting ${ }^{-1}$ and length of the three major roots cutting ${ }^{-1}$, after 60 days in the greenhouse, in two types of Tibouchina sellowiana cuttings, subjected to different concentrations of IBA. The collection of plant material occurred in October 2016, Curitiba-PR.

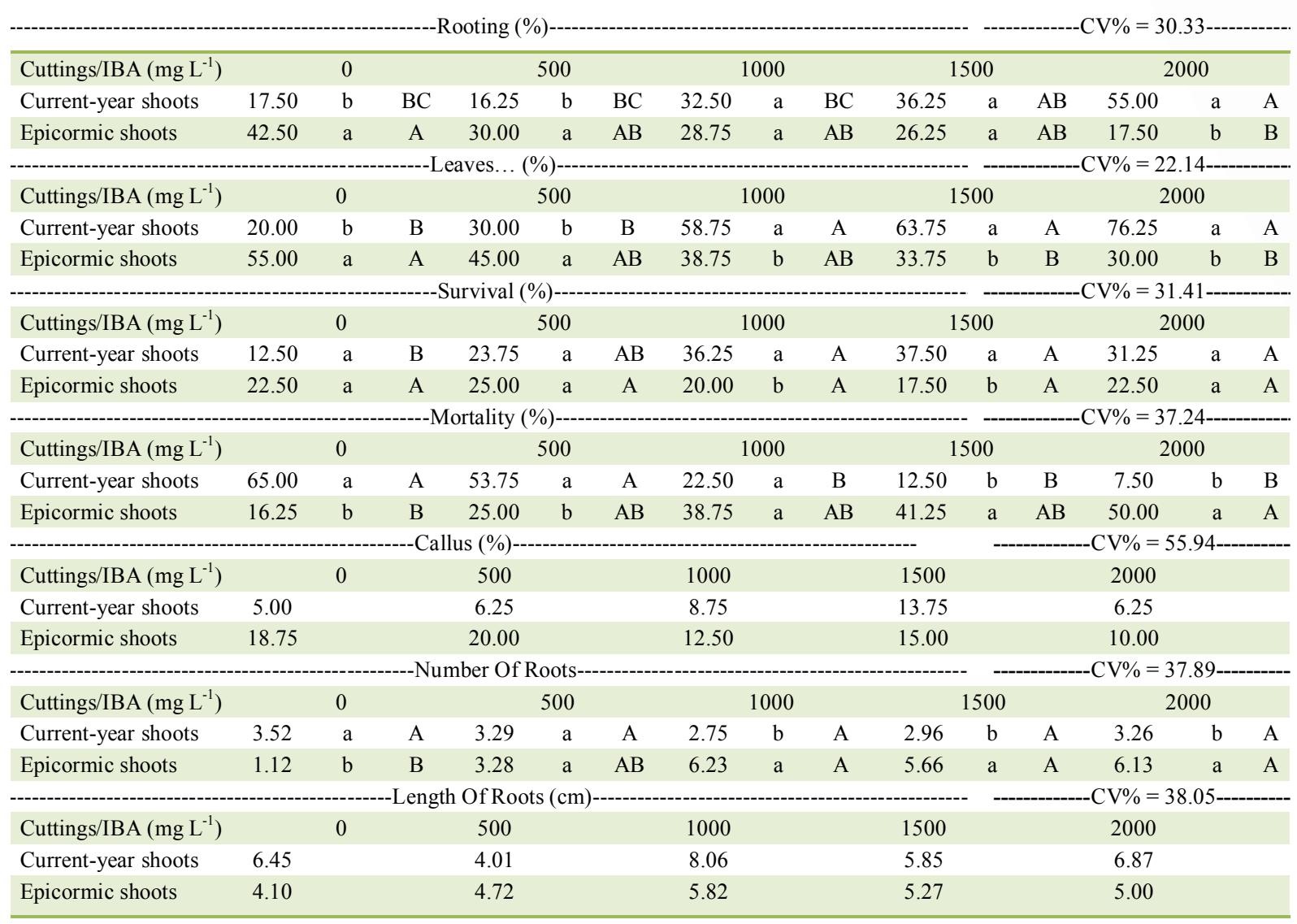

$\mathrm{CV} \%=$ Coefficient of variation (\%). Averages followed by the same lower case letter in column and capital letter on the line do not differ between them for Tukey test at $5 \%$ probability.

polysaccharides, contributing to the increase of the levels of physiologically active sugar required to supply the energy requirements necessary for the emission of the roots (HUSEN \& PAL, 2007).

Furthermore, longer roots could mean a greater ability to exploit the available resources, besides better fixation in the soil (HARTMANN et al., 2011). However, for the root length, there was no significant difference among the concentrations of IBA and between the two types of cuttings (Table 1). Lack of influence of IBA on this variable has also been observed in other studies, including with the gender Tibouchina. In general, values approximate to the present study occurred, with averages ranging from $1.70 \mathrm{~cm}$ to $13.14 \mathrm{~cm}$ (BORTOLINI et al., 2008; NIENOW et al., 2010; PEREIRA et al., 2015b).

\section{Experiment II - clonal mini-garden management and mini-cutting}

There was a high survival of mini-stumps (over $80 \%$ ) regardless of time of collection (Figure 1a). Even under winter, there was no reduction in the percentage due to the less favorable climatic conditions of this season. This result reflected the adaptability of the material to the environmental and nutritional conditions provided in the shade house and shows the mini-stumps strength maintenance throughout the experimental period (12 months). Small reduction in survival observed in the summer (last season to be evaluated) was possibly related to the longer maintenance period of mini-stumps. These results indicated the potential of Tibouchina sellowiana for the vegetative regeneration of mini-stumps due to the successive collections of mini- 


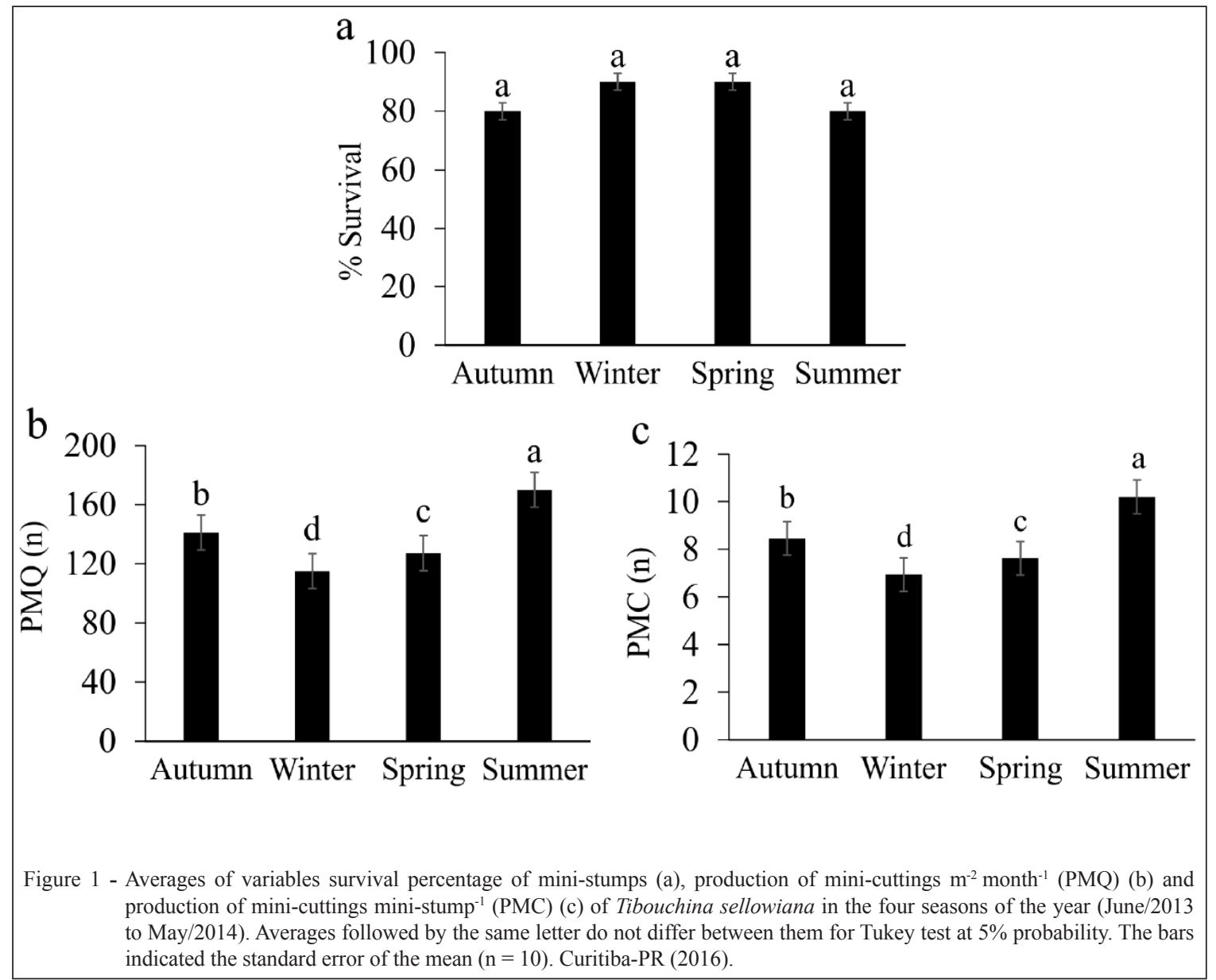

cuttings, allowing adoption of mini-cutting technique as a potential alternative in the propagation of this species.

Regarding mini-cutting productivity $\mathrm{m}^{-2}$ month $^{-1}$ (PMQ), there was significant difference between treatments. Summer was the period that provides greater average productivity (170 minicuttings $\mathrm{m}^{-2}$ month $^{-1}$ ) (Figure $1 \mathrm{~b}$ ). This result was consistent with what we expected, since in the warm seasons the species were in full vegetative growth, with the issuance of buds and young leaves, contributing to the development of new shoots. Other studies have also reported the highest productivity of mini-stumps in periods at elevated temperature (FERRIANI et al., 2011; PIRES et al., 2015). In the colder seasons, the short days associated with low temperatures exerted a negative influence on the translocation of plant compounds and photosynthesis due to the inhibition of the entry of phosphates into chloroplasts (LAWSON et al., 2012), causing stress of the mini-stump submitted to repeated collections and; consequently, lower productivity. Similarly, the summer showed highest values for PMC (10.20 minicuttings mini-stump ${ }^{-1}$ ) (Figure 1c). These results are superior to those obtained for other species (DIAS et al., 2012); however, we must consider the influence of the different systems used.

For evaluations in the greenhouse, the survival of mini-cuttings at 45 and 60 DAI was high (above $80 \%$ ), with no statistical difference between the seasons. The period and the maintenance in greenhouse proved to be adequate, as the results for mini-cuttings survival (Figure 2). The satisfactory control of environmental conditions in the greenhouse is highlighted as a major factor for rooting success. Thus, there is an environment conducive to maintenance of cell turgor, increasing the plant survival after transferring them to less controlled environments (WENDLING et al., 2010).

Regarding the variable percentage of roots grown in the plastic tube bottom (RFT) at 60 DAI, the 


(

highest value was obtained in the summer $(56.25 \%)$, followed by spring $(43.23 \%)$. The colder seasons possibly did not provide the ideal climatic conditions for roots development, since the materials collected in the fall $(25.52 \%)$ and winter $(23.96 \%)$ showed significantly reduced percentage. As mentioned earlier, in spring and summer the mini-stumps presented themselves in full vegetative growth and possibly with higher concentrations of endogenous auxin, carbohydrates and other substances, favoring rooting (BORTOLINI et al., 2008; HARTMANN et al., 2011). This possibility is in agreement with the literature, which indicated, among other factors, that the climatic variations (BORTOLINI et al., 2008) and the physiological conditions of the mother plant (WENDLING et al., 2014) influence the success of the vegetative propagation of the species.

Similar to the assessments in the greenhouse, the highest percentages of survival $(52.10 \%$ and $66.10 \%)$ and shoots emission in minicuttings $(47.90 \%$ and $65.10 \%)$ occurred in the spring and summer, respectively. These percentages were statistically higher than those obtained in the autumn
$(43.20 \%$ and $38.20 \%)$ and winter $(42.70 \%$ and $40.60 \%$ ) for survival and issuing shoots, respectively.

\section{CONCLUSION}

Cuttings taken from epicormic shoots feature superior results for vegetative propagation of Tibouchina sellowiana compared to current-year shoots cuttings, eliminating the use of IBA. The high survival of mini-stumps, production and mini-cuttings survival in greenhouse demonstrate the feasibility of mini-cutting technique for the species, being summer the most appropriate time to collect the mini-cuttings.

\section{REFERENCES}

BARBOSA, J.M. et al. Efeito do substrato, temperatura e luminosidade na germinação de sementes de quaresmeira. Revista Brasileira de Sementes, v.10, n.3, p.69-77, 1988. Available from: <http://www.bibliotekevirtual.org/revistas/RBS/v10n03/ v10n03a06.pdf $>$. Accessed: Jan. 10, 2016. doi: 10.17801/01013122/rbs.v10n3p69-76.

BONA, C.M.; BIASI, L.A. Influence of leaf retention on cutting propagationg of Lavandula dentate L. Revista Ceres, v.57, n.4, 
p.526-529, 2010. Available from: <http://www.scielo.br/pdf/ rceres/v57n4/a14v57n4.pdf $>$. Accessed: Jan. 10, 2016. doi: 10.1590/S0034-737X2010000400014.

BORTOLINI, M.F. et al. Tibouchina sellowiana (Cham.) Cogn.: Enraizamento, anatomia e análises bioquímicas nas quatro estações do ano. Ciência Florestal, v.18, n.2, p.159-171, 2008. Available from: <http://ainfo.cnptia.embrapa.br/digital/ bitstream/item/30243/1/Tibouchina-sellowiana-Cham.-Cogn.ENRAIZAMENTO-ANATOMIA-E-ANALISES.pdf $>$. Accessed: Jan. 14, 2016. doi: 10.5902/19805098454.

DIAS, P.C. et al. Estaquia e miniestaquia de espécies florestais lenhosas do Brasil. Pesquisa Florestal Brasileira, v.32, n.72, p.453-462, 2012. Available from: $<\mathrm{http}: / / \mathrm{pfb} . c n p f . e m b r a p a . b r / p f b /$ index.php/pfb/article/view/388/289>. Accessed: June 17, 2015. doi: 10.4336/2012.pfb.32.72.453.

FERRIANI, A.P. et al. Produção de brotações e enraizamento de miniestacas de Piptocarpha angustifolia. Pesquisa Florestal Brasileira, v.31, n.67, p.257-264, 2011. Available from: <http:// www.gepe.ufpr.br/pdfs/Producao\%20de\%20brotacoes $\% 20 \mathrm{e} \% 20$ enraizamento $\% 20 \mathrm{de} \% 20$ miniestacas $\% 20 \mathrm{de} \% 20$ Piptocarpha $\% 20$ angustifolia.pdf $>$. Accessed: Jan. 12, 2016. doi: 10.4336/2011. $\mathrm{pfb} .31 .67 .257$.

FRAGOSO, R.O. et al. Maintenance of leaves and indolebutyric acid in rooting of juvenile Japanese Flowering Cherry cuttings. Revista Brasileira de Ciências Agrárias, v.10, p.97-101, 2015. Available from: <http://www.redalyc.org/articulo. oa?id=119038296014>. Accessed: Nov. 02, 2015. doi: 10.5039/ agraria.v10i1a5111.

FREITAS, T.A.S. et al. Desempenho radicular de mudas de eucalipto produzidas em diferentes recipientes e substratos. Revista Árvore, v.29, n.6, p.853-861, 2005. Available from: $<\mathrm{http} / /$ www.scielo.br/pdf/rarv/v29n6/a03v29n6.pdf $>$. Accessed: Nov. 02, 2015. doi: 10.1590/S0100-67622005000600003.

HARTMANN, H.T. et al. Hartmann \& Kerster's plant propagation: principles and practices. New Jersey: Prentice Hall, 2011.915p.

HUSEN, A.; PAL, M. Metabolic changes during adventitious root primordium development in Tectona grandis Linn. f. (teak) cuttings as affected by age of donor plants and auxin (IBA and NAA) treatment. New Forests, v.33, p.309-323, 2007. Available from: <http://link.springer.com/article/10.1007/s11056-006-90307>. Accessed: Nov. 15, 2016. doi: 10.1007/s11056-006-9030.

LAWSON, T. et al. Improving yield by exploiting mechanisms underlying natural variation of photosynthesis. Current Opinion in Biotechnology, v.23, n.2; p.215-220, 2012. Available from: $<\mathrm{http} / / / \mathrm{w} w \mathrm{w}$. sciencedirect.com/science/article/ pii/S0958166911007555\#>. Accessed: Nov. 15, 2016. doi: 10.1016/j.copbio.2011.12.012.

NIENOW, A.A. et al. Enraizamento de estacas de quaresmeira em duas épocas e concentrações de ácido indolbutírico. Revista Brasileira de Agrociência, v.16, n.4, p.139-142, 2010. Available from: <https://www.periodicos.ufpel.edu.br/ojs2/index.php/ CAST/article/view/2022/1859>. Accessed: Jan. 14, 2016. doi: 10.18539/CAST.V16I1-4.2022.

OSTERC, G.; ŠTAMPAR, F. Differences in endo/exogenous auxin profile in cuttings of different physiological ages. Journal of plant physiology, v.168, p.2088-2092, 2011. Available from: <http:// www.sciencedirect.com/science/article/pii/S0176161711003427>. Accessed: June 17, 2015. doi: 10.1016/j.jplph.2011.06.016.

PEREIRA, M.O. et al. Resgate vegetativo e propagação de cedro-australiano por estaquia. Pesquisa Agropecuária Brasileira, v. 50, n.4, p.282-289, 2015a. Available from: <http://www.scielo. br/pdf/pab/v50n4/0100-204X-pab-50-04-00282.pdf>. Accessed: Nov. 15, 2016. doi: 10.1590/S0100-204X2015000400003.

PEREIRA, M.O. et al. Enraizamento de estacas de Tibouchina moricandiana var. vinacea em função da forma de aplicação e concentrações de AIB. Revista de Ciências Agroveterinárias, v.14, n.3, p.210-216, 2015b. Available from: $<\mathrm{http}: / /$ revistas.udesc.br/index.php/agroveterinaria/article/ view/223811711432015210/pdf_2>. Accessed: Dec. 11, 2015. doi: $10.5965 / 223811711432015210$.

PIRES, P. et al. Sazonalidade e soluções nutritivas na miniestaquia de Araucaria angustifolia (Bertol.) Kuntze. Revista Arvore, v.39, n.2, p.283-293, 2015. Available from: <http://www.redalyc. org/articulo.oa? $\mathrm{id}=48839479008>$. Accessed: Dec. 12, 2015. doi: 10.1590/0100-67622015000200008.

RICKLI, C.H. et al. Origem de brotações epicórmicas e aplicação de ácido indolbutirico no enraizamento de estacas de Vochysia bifalcata Warm. Ciência Florestal, v.25, n.2, p.385-393, 2015. Available from: <http://www.scielo.br/pdf/cflo/v25n2/01039954-cflo-25-02-00385.pdf $>$. Accessed: June 17, 2015. doi: $10.5902 / 1980509818457$.

STUEPP, C.A. et al. Vegetative propagation of mature dragon trees through epicormic shoots. Bosque, v.35, n.3, p.337-345, 2014. Available from: <http://www.gepe.ufpr.br/pdfs/Vegetative $\% 20$ propagation $\% 20$ of $\% 20$ mature $\% 20$ dragon $\% 20$ trees $\% 20$ through\%20epicormic\%20shoots.pdf $>$. Accessed: Jan. 09, 2016. doi: $10.4067 / \mathrm{S} 0717-92002014000300008$.

STUEPP, C.A. et al. Ex vitro system production of Acer palmatum plants propagation by minicuttings technique. Revista Cerne, v.22, n.3, p.355-364, 2016. Available from: <http://www.scielo.br/ pdf/cerne/v22n3/2317-6342-cerne-22-03-00355.pdf $>$. Accessed: Nov. 17, 2016. doi: 10.1590/01047760201622032147.

XAVIER, A. et al. Silvicultura clonal: princípios e técnicas. Viçosa: UFV, 2009. 272p.

WENDLING, I. et al. Mini-cuttings technique: a new ex vitro method for clonal propagation of sweetgum. New Forest, v.39, p.343-353, 2010. Available from: <http://link.springer.com/ article/10.1007/s11056-009-9175-2>. Accessed: Nov. 11, 2015. doi: $10.1007 / \mathrm{s} 11056-009-9175-2$.

WENDLING, I. et al. Maturation and related aspects in clonal forestry - Part I: concepts, regulation and consequences of phase change. New Forest, v.45, n.4, p.449-471, 2014. Available from: $\quad<$ http://link.springer.com/article/10.1007\%2 Fs11056-014-9421-0>. Accessed: June 18, 2015. doi: 10.1007/ s11056-014-9421-0.

WENDLING, I et al. Topophysis in Corymbia torelliana $\mathrm{x} C$. citriodora seedlings: adventitious rooting capacity, stem anatomy, and auxin and abscisic acid concentrations. New Forests, v.46, p.107-120, 2015. Available from: <http://link.springer.com/ article/10.1007/s11056-014-9451-7>. Accessed: Nov. 15, 2016. doi: 10.1007/s11056-014-9451-7. 